\title{
The Role of Edutainment in Museums, Learn through Play
}

\section{Rasha Hussein Elsayed Moustafa}

$\mathrm{PhD}$ Candidate in Heritage \& Museum Studies Department, Helwan University

\begin{abstract}
:
In this paper shows the importance of learning through playing which is known as "edutainment" and the effective ways of learning through different ways like using the different activities like using technology through teaching which will be more effective during education.
\end{abstract}

\subsection{Introduction:}

It is widely accepted that playing could be a vehicle for developing the way of thinking. The idea of combining education with entertainment has been widely used for educational purposes. Two commonly known terms that most people are 
familiar with are "learn through play" and "edutainment". In the most basic form, the focus of edutainment is learning through play. Nevertheless, there are some differences between them. Thus, this is the focus of this paper to analyze their similarities and differences in terms of definition, importance, effectiveness and exemplification of successful cases in some learning foundation in school.

\subsection{Learn through play:}

"Play" is an activity involved during childhood from babyhood to early teenager years. It is also referred to some activities in adulthood as well.

So if there is enough time to play there is more creativity.

\subsection{Why playing is very important?}

Playing is very important because through playing human can acquire skills naturally without even knowing it in a most natural way, which will be a lifelong known activity.

All their skills will be developed through discussing, learning, exploring and through experiments.

Playing supports children in all aspects to develop their physical and mental development. This happens through cooperation, discussing, helping, and sharing their social experience.

\subsection{What do children need in order to play?}

The most important thing the children need is the support from the adult as they should facilitate and support them. They are not mature enough so they need 
guidance from adults which will help them to make the right decision in a welcoming environment with the adult's companion so children will be able to explore, enjoy and plan ahead in a flexible way. Challenges are also very important which will make activities more effective for children.

\section{5 learning through playing:}

Playing is an essential activity to improve and develop children physically, mentally, emotionally, and socially. Play also teaches a child to react and handle circumstances around enjoyable activities. It is a way to learn because it uses all their senses to solve problem and understand their environment. Play prepares children for academic learning as they begin their school years. The idea to modify traditional games and toys into the classroom become one of the most essential areas. Therefore it makes sense to see play as having a valued and valuable place within a school curriculum. Teacher has an important role in helping children learn through play by selecting material they know, guiding them sparking their thinking by asking questions. When children are free to follow their interests and organize their own experiences, learning happen naturall

\subsection{Edutainment:}

Entertainment is using the education aspects while adding entertainment or amusement. The term edutainment is defined in several ways. Hutchison Encyclopedia, for example, defines edutainment as multimedia-related term, used to describe computer software that is both education and entertainment. The American Heritage Dictionary defines edutainment as "the act of learning through a medium that both educated and entertains." In conclusion, edutainment is the act 
of learning heavily through any of various media such as television programs, video games, films, music, multimedia, websites and computer software. Entertainment is the media and education is the content.

\subsection{Types of Edutainment}

Edutainment is an involving alternative to traditional education method. It can be organized in different ways:

Location-based edutainment which can be divided into two categories: interactive $\&$ participatory where children can play and participate in game, and noninteractive $\&$ spectator where children can just be seated and exploring (movie, science show, museums and zoos).

Edutainment by purpose and content consists of informal education which is to improve learners' life control, and skills education which is to give experiences, like simulations.

Edutainment by target group includes motivation-oriented (learners who have same interest), and age-oriented (learners who have same age)

Edutainment by type of media contains: edutainment on TV included: comedic drama, historical drama, sketch comedy, skills and travel; computer edutainment included game types: adventure, quiz, role-play, strategy, simulation, and experimental drama;

Edutainment on Internet included: tele- teaching and tele-learning systems, and web-based educational systems; interactive television. This type of edutainment 
uses the advent of digital television to provide the interactivity via software and hardware and connect with other telecommunication systems.

\subsection{Edutainment: in museums}

There are more for-profit types of location-based edutainment businesses around such as theatres, museums, zoos, aquariums, planetariums, historical sites, as well as children's edutainment centers. Many different kind of media used for edutainment.

Most studies show that play-based learning session proved to be successful in both formal and informal situations and they agreed that play is an important educational rule, especially during their childhood.

Researchers suggest that education administrators should consider play as a method of learning with new technologies beyond the foundation stages. The school of future may look more like a park or interactive museum than the traditional classroom. They also forecast that within the next decade the technologies and content development will allow policy makers to rethink the entire process of education. Teachers will play significant role as guide and nurturers. They can use more interactive edutainment mediums and act as the entertainment actors. Learner can enjoy more interactive classroom while teachers can also monitor and analyze the performance of students.

\section{The effectiveness of "learn through play" and "edutainment"}


Social behavior :Self-control, more positive social interacts and companionship, more altruistic behavior, less stereotyped views of other, cooperative, helping, sharing, solving social problems, understand their life experiences, ability to take turn, negotiate, compromise, work out conflict.

Cognitive development: Memory, creativity \& divergent thinking, extending skills of mathematical reasoning, basic skills such as counting, reading, and writing.

Intellectual development: Resolving problems, understanding how things work, devising strategies Emotional development Love, caring, empathy, curiosity, focusing attention on task, lower anxiety.

Physical development: Develop gross muscle control, eye hand coordinative, coordination of movement \& speed, a critical precursor to reading and writing skills.

Therapeutic effects: Health care (learn good eating habits from computer game.

Brain development: increase neural structure. 


\section{CONCLUSION}

"Learn through play" and "edutainment" are important areas that both use entertainment activity for learning. While learn through play is a much broader term in fun activity, edutainment relies heavily on technology, especially computer software. They are effective teaching strategy both inside and outside school. Play activity has a vital role in shaping learners' scientific, mathematics literacy as well as their language skill. This paper has presented an analyst into the two areas: "learn through play" and "edutainment". Similarities and dissimilarities have been presented. 


\section{REFERENCES:}

[1] Bauer, H. Science literacy in child's play. From http://idra.org/Newslttr/1996/Apr/Bauer.htm

[2] Buckingham, D. and Scanlon, M. Selling learning: Towards a political economy of edutainment media, Media, Culture and Society, 27,1 (2005), 41-58.

[3] Crocker, J. Active learning systems. ACM Computer in Edutainment, 1,1 (Oct. 2003)

[4] Farne', R. Pedagogy of play. Topoi, 24 (2005)

[5] Gros, B. The impact of digital games in education. First Monday, 8,7 (July 2003)

[6] Harvey, J. The market for educational software. Rand corp., Santa Monica, CA, 1995.

[7] Hussain, H. and Eshaq, A. The design framework for edutainment environment. In Behesthi, R. in Advances in Design Sciences \& Technology. Europia Publication, France, 2001, 81-90.

[8] Krotoski, A. Learning from games and games in learning. Guardian Newspaper Limited, (Jan. 28, 2005)

[9] Lindon, J. What is play. National Children's Bureau, London, 2002. 
[10] Marinelli, D. and Pausch, R. Edutainment for the college classroom. The Chronicle of High Education, 50, 28 (Mar. 2004), B.16

[11] Morgan, A. and Kennewell, S. The impact of prior technological experiences on children's ability to use play as a medium for developing capability with new ICT tools. ICT Research Bursaries, Becta, 2005.

[12] Noss, R. and Hoyles, C. Learning through play: Playing through learning. From http://www.ioe.ac.uk/playground/Europe Siena-Panel-proposal.htm

[13] Rauterberg, M. Positive effects on entertainment technology of human behavior. In Jacquart, R.

(Ed.) Building the Information Society, IFIP, Kluwer Academic Press, 2004.

[14] Resnick, M. Edutainment? No thanks. I prefer playful learning. In Associatzione Cicita. 1, 1 (2004), 2- 4.

[15] Rogers, C.S. and Sawyers, J.K. Play in the life of children, from http://chandlerscholl.org/teacher/www/freeplay.pdf

[16] Sconduto, D. Desktop videoconferencing in English as a second language/ English as foreign language education. From http://www.englishmeeting.com/Thesis.htm

[17] Susan, M. Revisiting edutainment. Technology \& Learning, 16,8 (May/Jun. 1996), 42,7

[18] Trister, D. and Bickart, T. Preschool for parents: What every parent need to know about preschool. Sourcebooks, Inc., 1998. 


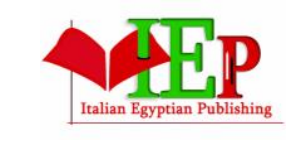

ISSN: 2735-4415
INTERNATIONAL JOURNAL OF

MULTIDISCIPLINARY STUDIES IN ARCHITECTURE AND CULTURAL HERITAGE

VOLUME4, ISSUE 1, 2021, $114-123$.

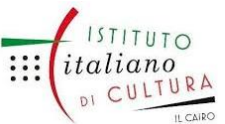

www.egyptfuture.org/ojs/

[19] Venkateswaren, T. Communicating science through play, games and simulations (SciFun). Indian Journal of Science Communication, 3, 1

Received: April 2021

Accepted: June 2021 